Portland State University

PDXScholar

1977

\title{
Quality of life assessment of chronic hemodialysis patients at the Artificial Kidney Unit of Good Samaritan Hospital and Medical Center
}

\author{
Karen Jones Whittle \\ Portland State University \\ Michael Tripp \\ Portland State University \\ Bruce De Young \\ Portland State University
}

Follow this and additional works at: https://pdxscholar.library.pdx.edu/open_access_etds

Part of the Health Psychology Commons, Medicine and Health Commons, and the Social Work Commons

Let us know how access to this document benefits you.

\section{Recommended Citation}

Jones Whittle, Karen; Tripp, Michael; and De Young, Bruce, "Quality of life assessment of chronic hemodialysis patients at the Artificial Kidney Unit of Good Samaritan Hospital and Medical Center" (1977). Dissertations and Theses. Paper 1840.

https://doi.org/10.15760/etd.1839

This Thesis is brought to you for free and open access. It has been accepted for inclusion in Dissertations and Theses by an authorized administrator of PDXScholar. Please contact us if we can make this document more accessible: pdxscholar@pdx.edu. 
QUALITY OF LIFE ASSESSMENT OF CHRONIC HEMODIALYSIS

PATIENTS AT THE ARTIFICIAL KIDNEY UNIT OF GOOD

SAMARITAN HOSPITAL AND MEDICAL CENTER

PORTLAND, OREGON

by

KAREN JONES WHITTLE

MICHAEL TRIPP

BRUCE DE YOUNG

A report submitted in partial fulfillment of the requirements for the degree of

MASTER OF SOCIAL WORK

Portland State UnIversity 1977

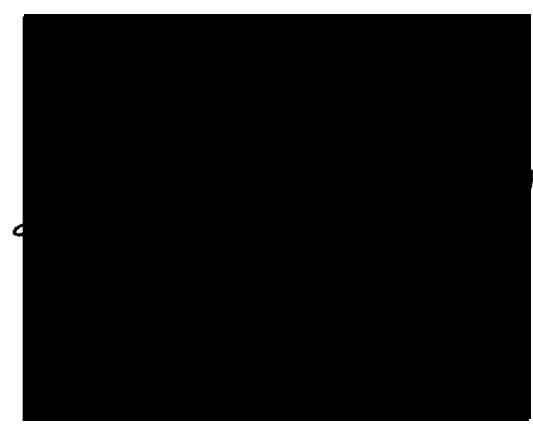




\section{ACKNOWLEDGEMENTS}

This research was made possible with the help of many people. Unfortumately all of them cannot be named. The help they provided is nevertheless greatly appreciated.

We wish to thank Sue Sakai, Director of Social Services at Good Samaritan Hospital and Medical Center, for helping us to focus the scope of this study. Special thanks are due to Tom Chambers, Social Worker, also at Good Samaritan, for giving so generously of his time and particularly for writing the cover letters used in the study.

Much appreciation is also expressed to Deane Clarkson and Susan Hines at the Regional Research Institute for Human Services, who gave freely of their time and expertise by providing computer programs, rums, and consultation.

We especially wish to thank the dialysis patients who participated in this study and to acknowledge their openness and willingness to share their thoughts and feelings about their personal 1ives. 
TABLE OF CONTENTS

PAGE

ACKNOWLEDGEMENTS . . . . . . . . . . . . . . . . 11

LIST OF TABLES ....................... . . . . . v v

CHAPTER

I INTRODUCTION . . . . . . . . . . . . . 1

Rationale ................ 2

Definition of Terms ............ . 3

Function of Kidneys and Treatment of

Chronic Renal Fallure .......... 4

II SEARCH OF THE LITERATURE . . . . . . . . . . . 8

III METHODOLOGY ................. 16

IV OVERVIEW OF STUDY POPULATION . . . . . . . . . 21

Activities of Daily Living . . . . . . . 21

Work and Finances . . . . . . . . . 24

Physical Condition . . . . . . . . 26

Emotional state ............. 27

Supportive Relationships . . . . . . . 30

Spiritual Aspect and LIfe Cholces . . . . . 31

Description of Patients' Responses to

Open-Ended Questions.......... 32

Summary ................. . . 36

v FINDINGS ........................... 39 
V FINDINGS continued

Statistical Tests of Home and Center

Patient Groups .......... 39

Statistical Tests of Home and Center

Patient Groups by Sex ..........

Statistical Tests of Male and Female

Patient Groups .......... . 4 43

Statistical Tests of Response Groupings . . . . 44

Rotated Factor Analysis of 22 Variables . . . . 46

Sumnary .................. 48

vI SUMMARY ........................ 50

Soclal Work Implications . . . . . . . 50

Research Implications . . . . . . . 52

Critique of study . . . . . . . . . 53

Conclusion ............. . . 54

REFERENCES . . . . . . . . . . . . . . . . 55

APPENDIX A : QUESTIONNAIRE . . . . . . . . . . . 57

APPENDIX B : DEMOGRAPHIC PROFILE OF STUDY POPULATION . . . . • 66

APPENDIX C: ROTATED FACTOR MATRIX OF 22 VARIABLES . • • • • • 71 
LIST OF TABLES

TABLE

PAGE

I Factors Seen as Causing Greatest Concern (Number

Responding and Percent) . . . . . . . . . . . 32

II Factors Seen as Improving Quality of Life (Number

Responding and Percent) . . . . . . . . . . . 34

II Additional Patient Comments . . . . . . . . . . . . . . 35

IV Evaluation of Classification Function for Home and

Center Patients Based on Discriminant Analysis

of 22 Variables . . . . . . . . . . . . . 40

V Evaluation of Classification Function for Home Male

and Female Patients and Center Male and Female

Patients Based on Discriminant Analysis of 22

Variables . . . . . . . . . . . . . . . 41

VI Evaluation of Classification Function for Male and

Female Patients Based on Discriminant Analysis

of 22 Varlables . . . . . . . . . . . . . . 43

VII Evaluation of Classification Function for Total

Patient Group Based on Responses to Choices

in Life Question ............ 45

VIII Dialysis Patients by Age . . . . . . . . . 67

IX Dialysis Patients by Sex . . . . . . . . . . . . . 67

X Dialysis Patients by Marital Status . . . . . . . . . . 68 
XI Dialysis Patients by Marital Status and Sex....... 68

XII Person(s) with Whom Patient Lives . . . . . . . 69

XIII Age and Number of Patients' Children . . . . . . 69

XIV Average Number of Children Per Family . . . . . . 70

XV Length of Time on Dialysis . . . . . . . . . 70

XVI Rotated Factor Matrix of 22 Variables . . . . . . . 72 


\section{CHAPTER I}

\section{INTRODUCTION}

To remain alive, an individual who experiences chronic renal failure must enter into a treatment course which only tenuously prolongs his Iffe as an artificial kidney patient, and then only with severe limitations in nearly every area of his life.

The medical situation of the dialysis patient is one of continuIng sickness with myriad symptoms. Because of physical limitations, loss of membership in groups, and changes in primary relationships and way of Iffe are common, if not inevitable. Changes or adjustments to a new and demanding life style may be perceived by the dialysis patient as radical restrictions and limitations of his pre-morbid life style. He must face the unavoidable fact that his continued extstence is contingent upon his being attached two or three times a week for five to eight hours at a time to an artificial kidney machine. As Viederman points out, "Patients rather readily enter into a love/hate relationship with this machine which becomes both the preserver of their IIfe and the tyrant that symbolizes the limitations of their freedom." 1

The purpose of this study was to evaluate certain factors that affect the quality of life experienced by the chronic hemodialysis patient population served by the Artificial Kidney Unit at Good Samaritan

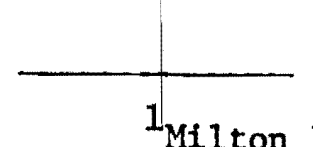

${ }^{1}$ Milton Viederman, "Adaptive and Maladaptive Regression in Hemodialysis," Psychiatry, Vo1. 37, (February, 1974): 68. 
Hospital and Medical Center,. Portland, Oregon. The intent of the study was to discover if there was a significant difference in quality of life between patients who dialyzed at home and patients who dialyzed at the Artificial Kidney Untt (center patients).

For the purposes of this study, House, Livingston and Swinburn's definition of quality of life was used. Their definition states that quality of life is a function of the percelved conditions affecting a selected population and the subjective attitude toward those conditions held by persons in that population. ${ }^{2}$ The percelved conditions with which this study is concerned are: activities of dally living, work and finances, physical condition, emotional state, supportive relationships, spiritual aspects, and choices in 1ife. The patients' perceptions of themselves in relation to each of these areas constitutes their subfective attitudes about them.

\section{RATIONALE}

Several reasons may be given for such a study at this time.

1. Medicare funding, which covers approximately 80 percent of dialysis costs for most chronic renal failure patients, serves as a prototype for other possible national insurance programs focused on catastrophic 1llnesses. Recently Instituted federal guidelines now require that additional psycho-social information about this patient population

\footnotetext{
${ }^{2}$ Peter W. House, Robert C. Livingston, and Carol D. Swinburn, "Monitoring Mankind: The Search for Quality," Behavioral Science, Vol. 20, (January, 1975): 58.
} 
be gathered. ${ }^{3}$

2. Decisions concerning course of treatment involve considerations of cost, convenience, independence and responstbility, as well as other life quality values. Therefore, physiclans and others need feedback from patients about their feelings and attitudes in order that the best course of treatment can be decided upon and a base established with which to compare individual patients.

3. A better understanding may enhance the opportunity of medical and social service staff to expand and improve their understanding of, and personal service to dialysis patients with whom they work.

4. Patients may come to understand their own feelings better by having the opportunity to learn about the feelings of others in simflar circumstances.

\section{DEFINITION OF TERMS}

A number of terms used in this study which are specific to kidney disease and treatment are defined below.

1. Shunt: This term is used to describe the complete surgically prepared apparatus which is externally connected between an artery and vein. This external connection is made with plastic tubing (cannula) which extends from vessels through two small openings in the skin. The plastic tubes or cannula from each vessel are then connected end to end and lie close to the skin.

2. Chronic renal fallure: The slow destruction of normal kidney

3Federal Reglster, Vo1. 41, No. 108, (Thursday, June 3, 1976): $22,517-22,518$. 
tissue that occurs over months or years, and eventually requires dialysis or kidney transplantation or both to maintain IIfe and health.

3. Hemodialysis: The use of an artificlal kidney machine to maintain the chemical balance of the body. A treatment session on one of these machines is commonly known as a "run."

4. Home patients: Those who have an artificial kidney machine in their home and who dialyze there with the help of a relative or friend.

5. Center patients: Those who continue to live at home but who travel to and from the Artificial Kidney Unit several times each week to dialyze.

6. Artificial kidney machine: A machine through which a patient's blood is circulated in order to maintain the chemical and fluid balance of the body. ${ }^{4}$

FUNCTION OF KIDNEYS AND TREATMENT OF CHRONIC RENAL FAILURE

The following section will describe the function of the kidneys, the two types of kidney failure with emphasis on chronic kidney failure, and the method of hemodialysis treatment.

The kidneys, which help to maintain the body's chemical balance, have four main functions:

1. To rid the body of excess fluid

2. To rid the body of metabolic endproducts

3. To retaln the amount of fluids needed by the body, and to

${ }^{4}$ U.S. Department of Health, Education, and Welfare, Living with End Stage Renal Disease, Public Health Service Publication No. 76-3001 (Washington, D.C.: Government Printing Office), 43-45. 
retain the chemicals necessary to the body

4. To release into the bloodstream hormones that help control blood pressure and blood production. 5

There are two types of kidney fallure, called acute and chronic. The main differences between acute and chronic kidney failure relate to how rapidly the process occurs, the causes of the kidney failure, and the duration of the kidney failure.

Acute kidney fallure is the rapid stopping of kidney function which occurs in a matter of hours or days. There are many possible causes of acute kidney failure, including severe shock and reduced blood supply to the kidneys (as in internal bleeding or multiple body injuries), certain types of poisoning, specific types of kidney disease, and injury to or blockage of the blood vessels leading to the kidneys. In most cases of acute kidney fallure, the function of the kidneys is restored naturally within several weeks. Dialysis is required in most instances for a period of only a few weeks if kidney function returns. In some cases the kidney failure is permanent and therefore, it becomes chronic. 6

Chronic kidney fallure differs from acute in that destruction of normal kidney tissue occurs over a longer period of time. Most patients with chronic kidney fallure have no symptoms until far more than half of the kidney function is lost. At this point, high blood pressure, fatigue, weakness, or low blood count may first be detected.

$$
\begin{aligned}
& { }^{5} \text { Ibid., p. } 3 . \\
& { }^{6} \text { IbId., p. } 4 .
\end{aligned}
$$


When kidney function reaches approxdmately five percent of normal, or when 95 percent function has been lost, dialysis or transplantation is required to prevent progression of symptoms and maintain life. There are many possible causes of chronic kidney fallure, which may be inherited or acquired in childhood, adolescence, or adult life. Polycystic kidney disease is an example of an inherited disease that may lead to kidney failure in the middle adult years. The most common type of kidney disease leading to chronic kidney fallure is chronic glomerulonephritis in which there is an inflammation of the small filtering units of the kidney. Chronic kidney fallure may also be produced by long-standing diabetes and high blood pressure. ${ }^{7}$

There are two types of treatment for chronic kidney failure: hemodialysis and transplantation. As stated previously, hemodialysis is a method of using an artificial kidney machine to remove fluids and metabolic endproducts from the bloodstream. Blood is taken from a blood vessel in the arm or leg through a needle inserted in an internal fistula, or through the cannula of an external shunt. Following insertion in the blood vessel, the needle or cannula is attached to a tube which carries blood to the artificial kidney hemodialysis machine. The patient's heart pumps blood through the tube to the machine where the blood is treated. Then the blood is returned to the body through another needle that has been inserted into the vein. 8

The second type of treatment -- transplantation -- will be men-

${ }^{7}$ Ib 1d., p. 5.

8 Ib Id., p. 6 . 
tioned only briefly. Transplantation involves removing a kidney from a living relative, or from a cadaver, and implanting it through surgery into the kidney patient's body so that it will perform the functions of a normal kidney.

When patients experiencing chronic renal failure reach a point requiring dialysis treatments to sustain life, the decision must be made whether the patient will be trained to dialyze at home or be treated at the Artificial Kidney Unit. Considerations involved in these decisions include physical condition, maturity, distance from the Artificial Kidney Unit, and avallability of assistance from others, especially involving dialysis treatments and provision of transportation.

The purpose of this research is to study the influence of the disorder on the lives of dialysis patients. It w111 address itself to the problems and adjustments of the patient and his famfly in order that social work in particular may understand the range and intensity of problems to be confronted.

In the following chapters discussion will be presented concerning what the literature has to say about quality of 11 fe, methodology - how the study was conducted, an overview of the study population, findings, and summary. 
After the introduction of the permanent arterfo-venous shunt by Scribner and his associates in 1960 (16), maintenance hemodialysis became a practical possibility for the long-term care of patients with terminal renal disease. Since then, many investigators have reported behavioral and psychological observations of such patients $(1,11,6,5,8)$, and it is with the psycho-social component that this literature search is concerned. Without exception these reports emphasize the pervasive nature of the treatment regimen throughout most, if not all, areas of the patient's 1ffe, and point to numerous problems in adaptation:

Kidney fallure by its very nature Involves decreasing ability of the body to eliminate its waste products. The increasing concentration of these poisons in the system results in a variety of 111 effects throughout the body. The nervous system is particularly susceptible to such adverse effects, and consequently, "the very important basic mechanisms of attention and concentration are among the first to be involved." 9

In addition to generally reduced strength and endurance, the patient must adapt to the restricted use of a cannulated extremity - an

${ }^{9}$ Jonathan W. Cummings, "Hemodialysis - Feelings Facts Fantasies: The Pressures and How Patients Respond," American Journal of Nursing, Vo1. 70, No. 1, (January, 1970): 71. 
arm or leg in which the surgical connection of an artery and a vein is opened each time the patient is dialyzed. Clotting and infection of cannula is common as are gait impairment, arthritis, anemia, weakness, vomiting, pathological fractures, intestinal bleeding, insomnia, weight loss, and peptic ulceration $(1,17)$.

In the psycho-social realm one of the first concerns of the person beginning a course of dialysis treatments is financial. Chronic renal failure is a prolonged catastrophic 1llness, and although Medicare covers 80 percent of treatment expenses for most patients, the remaining 20 percent plus the cost of supplies often becomes a significant burden. The patient's share of the yearly cost of home dialysis can be $\$ 1,000$ to $\$ 1,500$, while treatments at a medical center for the same period of time may cost the patient $\$ 5,000.10$

A further complication of the financlal picture develops as patients who have been holding jobs find it increasingly difficult to maintain both their interest and efficiency in their work. Typically, they experience loss of job due to physical restriction, or decrease in job responsibilities because of time away from job for dialysis and treatment of complications. If the patient is male, a role reversal often occurs in which a wife may assume financial responsibility for the family.

Authors repeatedly reported $(19,8,7)$ that the major adaptational problem in hemodialys is lies in the area of emotional dependency. Dependence on the dialysis machine for survival is a reality. Note, how-

${ }^{10}$ Martin Neff, "Center Vs. Home Dialysis," Renal News, Vol. 5, (Spring 1975): 17 . 
ever, that this is not the dependency of a particular personality reaction, but rather an Imposed dependency which nonetheless "runs counter to the pervasive cultural accent on such values as independence and self-determination."11 Kaplan DeNour (8) belleves that acting-out behavior in the form of non-compliance with medical regime is attributable to a striving for independence. Writing about sulcidal behavior in chronic dialysis patients, Abram (2) suggested that the high incidence of sulcide is related to the difficulty of accepting dependency generated by passivity and Inactivity. Depression has been found by many authors $(6,5,1,19)$ to be a major problem. Most of them related depression to stresses induced by the mechanical difficulties and to the stresses of living with dialysis as a requisite for life maintenance. Social role disturbance is a natural outgrowth of concern about changing finances, strongly increased dependency, and chronic depression. In particular, the roles of breadwinner, disciplinarian, and decision-maker seem to be especially vulnerable to the effects of kidney disease and dialysis. Abdication of these roles results in a diminIshed self-concept and a relatively impoverished personality.

Some studies have noted the famlly problems which result from chronic dialysis, but there have been few attempts to determine actual changes which occur in the quality of a patient's home 1ife. Although the spouse of the dialysis patient has been portrayed as inttially makIng many sincere efforts to accommodate to the patient's limitations, a continuous process of decay tends to occur (4). Presumably the spouse,

${ }^{11}$ Cummings, p. 72 . 
who has a considerably emotional investment in the patient and whose Iffe style is interdependent with that of the patient, must be strongly affected by the changed circumstances.

Although no comments specifically concerned with female sexual response were found in the literature, reduced sexual potency is very common, reportedly affecting at least 80 percent of male patients (1). Diminished sexual desire and capability must significantly affect the whole fabric of the relationship between a man and his wife.

Because of physical limitations, loss of membership in groups and changes In way of life and living are often necessary. Most patients and their spouses have emphasized the unpredictability of feeling well and the difficulty this causes in planning or attending various social commitments .

Theoretically, a dialysis patient who begins treatments with no serfous complications could expect to live out a normal span of years. However, the extremely demanding treatment regimen coupled with the physical and psycho-social changes noted above stack the deck against him. But since it is "the only game in town," as one patient put it, the situation must be responded to. In fact, according to McKegney and Lange (14) most patients receiving chronic hemodialysis consider withdrawing from it if the quality of life they and/or their families experience is not sufficient.

In the Ifterature, at least three conceptual areas concerned with psycho-social aspects of dialysis patients' experiences have been the focus of theoretical considerations: the patient with chronic renal faflure as a marginal man, the concept of an external locus of control 
framework with regard to a patient's sense of personal power, and stages of adaptation to chronic hemodialysis.

As part of the socialization process, individuals internalize norms which prescribe the set of expectations for dealing with, or being, the 111 person as patient. The patient is assumed to be exempt from the performance of normal social obligations and from the responslbility of his own state. He is expected to be somewhat helpless and dependent on others, and finally, to get better and be cured or get worse and die.

Landsman (13) has described how this expectation results in conflict for the chronic renal patient. During the course of his illness, the patient with chronic renal disease usually experfences at least one crisis episode which requires his admission to a hospital for acute care. He finds himself dependent, passive, and in need of substantial medical attention. At this point he is quite within society's expectations and he is accepted as free from normal functioning. His confusion begins, however, when he reaches a stabilized medical status maintained by dialysis. His psychological difficulty is created by the contradiction that he feels better but that he is not and cannot be cured. Consequently, "It is the concept of perpetual treatment without cure that induces conflict in the patient since he is neither dying nor is he returned to society 'healed'."12

It is this contradiction between reality and society's expecta-

${ }^{12}$ Melanie K. Landsman, "The Patient with Chronic Renal Fallure: A Marginal Man," National Kidney Foundation Professtonal Membership Application, Reprints available from author, 3341 Warrensville Center Road, \#107, Cleveland, Ohfo, 44122. 
tion which Landsman sees as causing the chronic renal patient to become a marginal man in his own. right. He is, In this view, "suspended In a state of 1 imbo between the world of the sick and the world of the well, belonging to nelther, yet a part of both."13 Landsman believes that this marginality between illness and health is primarily responsible for many manifestations of Inner turmoil including non-compliance with medical regimen which she views as the patient's way of maintaining himself in the sick role. That is, by creating physical complications, he resolves to some extent his psychological stress and thereby gains a certain clarification of whether he is sick or well. Another view of the patient's lack of adherence to the treatment regimen has been presented by Goldstein and Reznikoff (10) who suggest that such behavior may be regarded as an attempt by the patient to reduce the anxiety resulting from the recognition of his tremendous responsibility in the treatment program. They also site the tremendous psychological stress constantly faced by these patients and represented by fear of death, loss of income, reductions in family and social status, uncertainty about the future, lack of stamina, changes in body Image, and worry about additional medical problems.

As an attempt to cope with such intense and continuous responsibility and anxiety, Goldstein and Reznikoff belleve the dialysis patient adopts an external locus of control with the result that his behavior is no longer perceived as 1ife-sustaining. Their investigation found that compared with patients with minor medical problems, patients 
on chronic hemodialysis evidence a significantly greater degree of external locus of control; that is, such patients belleve their behavior has little or no effect upon their condition, and in this manner, they seek to avoid the constantly intruding reminders of their tenuous hold on 1ife.

The third area of theorizing has focused on stages of adaptation to chronic hemodialysis. After studying patients' adaptation to chronic hemodialysis in the late $1960^{\prime} \mathrm{s}$, Abram (5) described a series of stages through which a dialysis patient passed. When entering dialysis, the patient was near death and much too dulled by his 111ness to care about his future. Apathy was the general attitude in this initial stage, A perlod of euphoria followed when the patient realized he had "returned from the dead" and was foyous over his fresh state. After a few weeks of dialysis, a state of anxiety developed as the patient became more and more aware of the life-maintaining equipment and procedures. The final stage described by Abram was the struggle for normalcy the patlent undertook in coping with his illness.

These progressive stages are not as characteristic today. In the $1960^{\prime}$ 's, patients were often in the process of dying, as evidenced by the symptoms of end-stage renal fallure, at the time they began dialysis. Although this is still occasionally true, more often patients are accepted into a hemodialysis program at an earlier phase in their renal failure. Consequently, the dramatic recovery and sense of euphorla are not as common today.

For the less physically 111 patient starting dialysis, Abram (3) described two general stages. The initial stage represents the acute 
psychological responses of patients including hope for future well-being and anticipated benefits from increased efficiency. A second and permanent stage follows in which the long-term adaptational process sets in, challenging all of the patient's resources with the growing realization that his activity away from the machine is slgnificantly reduced and that he may never feel completely well again. In this stage, anxlety over the unknown future changes to the realization that dialysis is a way of $11 f e$.

These theoretical areas - the concepts of the chronic renal patlent as a marginal man, of an extended locus of control framework, and of stages of adaptation - together attempt to explain much about the psycho-social conditions and reactions of the chronic dialysis patient. These conslderations are intended to provide a helpful perspective on the following attempt to obtain and assess subjective information on the life quality of these patients. 
CHAPTER III

METHODOLOGY

The purpose of researching this population of home and center kidney dialysis patients was to examine selected variables which presumably contributed to their quality of life. The investigation was based on the patients' subjective view of these variables. The following is the list of variables explored within the study:

1. leisure-time activities

2. change in social activities

3. positive or negative change in social activities

4. mobility restrictions

5. employment status

6. performance satisfaction if employed

7. satisfaction if not employed

8. financial situation

9. change in financial situation due to dialysis

10. general physical condition

11. appetite
12. sleep

13. changes in sex life

14. general emotional state

15. frequency of depression

16. feelings about being tied down to dialysis

17. care of oneself

18. emotional support from friends

19. emotional support from family

20. quality of intimacy with significant other

21. spiritual aspect

22. choices in life

The subjective variables were analyzed objectively through statistical means. No research hypothesis was set forth, but a hypothesis 
of an ad hoc nature was employed for the purpose of statistical testing: There is a significant difference between home and center kidney dialysis patients.

Ninety-three dialysis patients made up the study population at the Artificial Kidney Unit as of February, 1977. Because the population size was not unwieldly, the entire current population was polled. of this total of 93 patients, home and center patients were almost equally divided with 46 patients who dialyzed at home while 47 center patients traveled to the Artificial Kidney Unit for dialysis.

The research tool was a questionnaire which included 22 quantitative questions with a comment section following each question, three open-ended questions, and general base data (see Appendix A). The 22 questions used a five-point scale with equal appearing intervals. In 18 of the 22 questions, the interval numbers ranged from 5 as a high response rating to 1 as a low rating. These five points were tagged with appropriate verbal indicators. In four of the questions (\#9, \#13, $\# 15$, 非6), the scale was reversed.

In order to encourage patients to comment further or expand on questions, three open-ended questions were asked. The purpose of these was to address areas not directly referred to by the other 22 questions and to elfcit any additional information that may have been omfted. Stimulus questions were: biggest worry, what could make quality of life better, and any additional comments.

Base data or varlables included the following: age, sex, marital status, person or persons patient lived with (spouse, parents, children, other), length of dialysis, and whether the patient dialyzed at home or 
at the Artificial Kidney Unit (center).

The questionnaire was administered to eight professionals employed by the Artificial Kidney Unit as a pre-test. These individuals included nurses, social workers, and technicians. The purpose was to clarify specific questions and add new items. Appropriate additions and changes were made. The questionnalre was considered to be generally clear (1.e., particular words or phrases were not confusing and intent of questions was easily understood). No problems appeared in the actual returns from the patients.

The flrst mal1-out of the questionnalres included a cover letter from the staff soclal worker, as well as a self-addressed, stamped return envelope. The response rate on this first mall-out was 43 percent. A follow-up malling approximately three weeks later included a new cover letter and again a self-addressed, stamped envelope. With this followup, the response rate rose to 67 percent; 35 home patients and 27 center patients responded. To preserve the confidentiality of the patlents, no telephone or personal follow-up was undertaken.

Representativeness of the sample could not be tested satisfactorily in detall. Center patients were underrepresented, the probable effects of which can be seen from the analysis.

The statistical tests employed in analyzing the data were discriminant analysis, factor analysis, ch1 square and F-test. Discriminant analysis was used to discriminate between and among patient groups and responses by categories. Factor analysis was used to determine whether relationships among questions asked were perceived by the patients as the researchers had intended. Also, clusters of varlables were obtained 
by means of the factor analysis.

Discriminant analysis was used to allocate individuals to classes. Given that an Individual may have emanated from one of $k$ populations, the major problem was to allocate him to the correct population with minimum error, on the bases of multiple measurements on the individual. Another way to state this is that overlap in the distributions of the Individual variates may make it difficult to allot the observation to its correct population with certainty, but a function of the variates can be constructed, the discriminant function, which will allocate a member to one class or the other with a known probability of correctness. The function was chosen as usual so as to maximize this probability.

Discriminant analyses were used to determine whether it was possible to discriminate between home and center patient groups, home and center patient groups by sex, male and female patient groups, and response groupings categorized as poor-very poor, fair, and good-very good. Additionally, discriminant analysis showed the predictability of classifying patients into correct groups.

Factor analysis, the second method, was used to determine whether It was possible to reduce the set of variables to a lesser number of new variables each of which was a function of one or more of the original variables. For purposes of this study, the reduced variables will be referred to as dimensions.

Factor analysis was used to determine whether:

1. the 22 varfables could be reduced to a smaller number of dimensions. 
2. significant correlations existed among any of the 22 variables.

3. the manner in which responses were grouped by factor matrix after rotation reflected the way in which the questions were grouped in the questionnaire.

To determine if there was a significant difference between and among patient groups, an F-test was utilized where testing was done between two groups, and a chi square was employed where there were three and four groups.

The next chapter will present qualitative data on the sample population as a whole. 
CHAPTER IV

OVERVIEW OF STUDY POPULATION

This chapter will give a general descriptive summary of patients' feelings and attitudes about the quality of their lives. This information is presented in the following six life satisfaction categories: activities of daily living, work and finances, physical condition, emotional state, supportive relationships, the spiritual aspect, and life choices. Appendix B contains a demographic profile of the study population.

\section{ACTIVITIES OF DAILY LIVING}

Many of the daily activities for dialysis patients change as a result of entering a hemodialysis program, and adjustments to these necessary changes are important indicators of the quality of their lives. Patients were asked how they felt about their lelsure-time activities, changes in social activities, and any restrictions in elther of these two areas. The mean degree of negative to positive feeling about these aspects as a whole was a "fair" rating (3.00). On the subject of leisure-time activities, patients felt "fair" to "good" (3.42), higher than either of those mentioned above. Eight patients felt that the state of their physical condition kept them from being able to enfoy leisure pursuits. Comments like "I haven't felt well enough to engage in any," "I don't feel good enough to do any- 
thing," "not physically well enough to enjoy much" were character1stic In describing this aspect of their lives. Of those who did feel physically capable or well enough to engage in avocational interests, another eight patients were already involved in activities at a lower level of physical involvement prior to becoming 111 .

A varlety of less physically demanding lelsure activities that could be engaged in at home, such as sewing and gardening, were mentioned by those patients who displayed more positive feelings. In addition, a few comments were very positive. For example, "I have so many things I want to do, it seems like I don't have enough time to do them all," and "I'm a very active person and don't take time to sit around; my household and outside activities keep me busy all the time." Two persons reported that the dialysis process replaced leisure-time activities.

Social activities had changed in 71 percent of the cases. The accompanying feeling was "poor" to "fair" (2.24). Once again the physical limitations experienced by the dialysis patients imposed a significant life change upon social activities. Common responses to this question brought out the obvious relationship between feeling below par physically and being unable to engage in social activities. Typical responses were "I don't feel like doing it," "too weak and 111," "a problem of mobility -- not well enough to get out and get around." Key phrases describing the patient's inability to enjoy social activities were, "lack ambition," "no zest," "no energy," and "don't have the strength." Again, there were numerous comments concerning dialysis taking the place of past social activities. The remaining 29 percent 
of the patients indicated that their involvement in social activities had not changed.

Feelings concerning restrictions on abllity to get around on the average were "fair" (3.04). Eleven out of 22 patients commented that restriction on travel was a major loss. Examples were, "Travel is greatest loss," "Cannot take family on vacation," and "A vacation of any length of time would be revolved around my dialysis which I would find very time consuming and a disadvantage for even considering a trip." Another comment poignantly described restricted activities, "The only time I go shopping is for food, and I get very tired. I can't travel because the people I want to see are in another state and there's no money for me to have my treatment out of state. I feel the machine is my master."

Once again reference was made to tiring easily. One father wrote, "The only thing that hurts is not being able to play with my son very long at one time. We play when I'm able to catch the basketball."

In a more positive light, a few patients commented that the disease and dialysis were restricting, but they were thankful such a treatment was available.

Four conclusions concerning activities of dally living can be drawn. First, avocational and social activities are of a limited nature, and home activities are the standard. Second, such activities have changed for the worse and are directly affected by physical $11 \mathrm{mi-}$ tations. Third, the loss of travel is keenly felt by many. Freedom to come and go is not usually optional. Last, the majority appear to have adjusted, at least resignediy, to the limited dally activities. 


\section{WORK AND FINANCES}

of major concern to most dialysis patients is the whole area of employment and finances. Research Indicates that most patients, because of the physical 1imitations of the disease, must either quit working outside the home or severely limit their previous work. The clear majority of Good Samaritan kidney patients were no longer employed ( 77 percent). A small number of patients (13 percent) were able to continue their jobs in much the same manner as before. These people were employed at jobs that made extensive use of the telephone or had quiet activity desk jobs, "Work 40 hours a week. I go home early on the days of dialysis occasionally. Been very lucky because it is a desk fob." In addition, part-time work was engaged in by some. Generally, the patients who were employed, part- or full-time, felt "good" to "very good" (4.30) about how they were doing at work.

On the other hand, the 77 percent of the patients who were no longer working, generally gave a "fair" rating (3.03) as to how they felt about not working. It must be mentioned that this percentage includes some patients (five) who have retired and some (three patients) who have never worked or worked only infrequently. In explaining the "fair" rating, one-third of the patients who commented expressed the desire to work, but lack of energy and poor health made that very difficult. A typical statement was, "Would have no energy to work now." Also, some stated that they "missed the challenge that a job provides." Arranging a work schedule around dialyzing made employment for some a big problem.

In describing their financial situation, patients generally felt 
that their situation was "fair" (3.00). Of those who felt more positively than negatively about their finances, social securfty and health insurances were mentioned as reasons. Typical was, "Very lucky to have medicare and insurance." However, for those patients who saw a more negative situation, money worries were a very influential factor in their lives. Some commented that "medical bills were beyond their management," and many agreed that because of the combination of limited employment and their expensive disease, finances were very hard to deal with.

Related to the financial situation was the matter of how much change in the financial picture dialysis had caused. Overall, the patients felt that their financial situation had changed "somewhat" (2.94). Again, medical insurance had kept the financial aspect of life for many from drastic change. Many expressed thankfulness that they had insurance coverage. For example, "If KAO (Kidney Association of Oregon) had not helped, my finances would have been depleted," and 'The various insurances we have have covered things pretty well so far. One always wonders whether something will come up that won't be covered."

Generally, in reviewing employment and finances for kidney patients, those still engaged in employment fudged their performance as "good," those not working judged their feelings about this as "fair," and both groups viewed their present financial situation and related changes as not betng extreme. 
PHYSICAL CONDITION

Five indices were explored related to the physical states experienced by dialysis patients. They deal with feelings about general physical condition, appetite, sleep, sex, and ability to care for oneself. Judging this aspect of their lives, patients gave ratings of "fair" to "good" (3.28). The largest number of comments which focus on overall physical condition speak of feeling tired much of the time with reduced strength and endurance. Specific conditions mentioned include weakness, nausea, light headedness, and cannula infection. For example, "Have felt very weak and nauseous," "I am a little light-headed," and "TIred all the time."

Among comments about appetite, ten out of 16 who commented felt that their appetites were "too good," and consequently have difficulty controlling their food and fluid intake. Some of these comments included, "I'm hungry all of the time," "Can eat a horse," "Too good, I have trouble keeping my welght down and staying away from foods not okay to eat." Only two said they usually must force themselves to eat. The mean appetite response was 3.90 .

Twelve out of 15 responses concerning sleep indicate difficulty due to such things as "worry over finances," tension, nightmares and having slept during part of a daytime or evening dialysis run. One patient commented, "Sometimes I can't stay awake on dialysis and that makes it harder to sleep at night." Only three comments indicated little or no trouble sleeping. Here the mean was 3.40 or feelings of "fair" to "good."

of 19 comments about changes in sex 1ife, only one indicated "no 
change," two spoke of an improvement after having begun dialysis, and the rest reveal no sex life at all or a significantly reduced one at best. For example, "What sex life! None," "I don't think about it," "No sex since dialysis," and "I was much more interested in sex before my disease. I love my husband more than anything. Sometimes it's very difficult." Patients were "somewhat" to "considerably" concerned about changes in sex life (3.73).

Over two-thirds of the comments about ability to care for oneself reflected a sense of competence along with active involvement of the patient in the treatment regimen. For example, "I have learned to do all kinds of things for myself since this problem occurred," "I can do most things -- need help getting on the machine," "I'm able to take care of myself and I like 1t. I don't like to depend on others." The other six who commented indicated greater feelings of dependence. "I must always rely on someone," and "Hope this improves as I get stronger. Do not like to be dependent," were typical statements. Respondents felt "fair" to "good" about their ability to care for themselves (3.61).

\section{EMOTIONAL STATE}

Chronic 1llness such as renal failure usually results in emotional changes and upsets for the Individual. Depression is common as patients find the necessary adaptations taking up a great part of their lives. To explore this phase, Good Samaritan kidney dialysis patients were asked how they felt emotionally most of the time, how of ten they were depressed, and how they felt about being tied down by the machine and dialysis. 
First, the general emotional level of the patients was rated as "fair" to "good" (3.44). Of a total of 13 additional comments to this question, six patients described negative aspects. Such phrases as "very depressed," "very emotional," "feel so useless," "feel lonely," and "sometimes wish for death," describe the negative emotional feelings experienced. However, three patients related rather positive emotional states that were connected to supportive relationships with others. For example, one patient stated, "I feel very good emotionally because I understand my problem. The doctors, nurses, and technicians have educated me as to what's wrong, what to expect; therefore, I'm not in the dark." Another offers, "My church and friends help a lot in this area, plus my parents."

Statements of a philosophical nature were made by two patients to explain the emotional side of their lives. One stated, "I am not extremely happy, nor am I depressed. I try to use common sense." The other related, "Accept things you can't change and forget it."

Because the most common emotion felt by patients is depression, they were asked how often they were depressed. Here the mean response was 1 isted as 3.38 or "sometimes" to "often." Comments concerning the seriousness of the depression that some felt are indicated by, "Sometimes I just want to crawl in a hole and pull it in after me, but I can't because if I let anyone know I'm feeling' down, they start hovering." A second patient explains, "Have been most depressed since starting home training. Seems my whole life is centered around my kidney problem." A third commented specifically about the cause of depresston, "There's one thing that makes me very depressed -- the 
water. I'm always thirsty; and I worry about how much I drink."

On the other hand, some patients, three out of 12 who commented, did not appear to feel depressed very of ten as evidenced by, "Am in a good mood most of the time," and a rather mixed statement, "What have I to be depressed about. I have a fine wife. My boy and his good family live a few feet away. I hate the dialyzer, but who doesn't (if they have to live with one)."

Finally, just how "tied down" patients felt in relation to dialysis was asked. In view of the responses to emotional state and depression, one might have expected an equally high score in this area. However, the mean was 2.65 or the rating was "little" bothered to "somewhat" bothered about belng tied down. Six of 16 patients commented that the dialysis process kept them from being able to do the things they wanted to get done or the things they used to do. One patient commented that he was bothered by being tied down to dialysis, "Only because I have three nights a week that I'm on dialysis when I couid be doing the things I want to get done." The many hours and numerous evening or day rums on dialysis were perceived generally as a bother or a bore, but at the same time a necessity to be lived with. Examples of this were, "I get bored with six hours of dialysis," "hours (on dialysis) are more of a bother," and "It curtalls my freedom somewhat, but since it is necessary I can live with it." Finally, freedom to travel was perceived as a problem in two cases, "Especially in summer, you can't go for weeks and vacations." 
SUPPORTIVE RELATIONSHIPS

The stringent demands of the dialysis patient's treatment regimen suggest the importance of supportive relationships in the life of such a patient. Three relationship questions focused on friends, family and closest intimate other.

of 11 comments about emotional support from friends, seven reflect strong positive feelings such as "always giving a helping hand," and "my friends are super people.". The other four apparently do not experience such support. One sees acquaintances as "most busy with own lives." Another relles on the bishop of her church, and yet another finds acquaintances' curiosity about the details of dialysis "upsetting." Patients thought their friends were more than supportive (4.40).

Strong famfly, emotional support is suggested in seven of 11 comments: "I have the finest family in the world; can't be beat." The other four reflect varied problems: "If they wouldn't hover so, I would be better; I tend to be more demanding of them than others. I've never been sick before and my husband, tho he is also 111 , can't understand that I can't do as I always have." Here the mean was 4.38 or again a "good" to "very' good" rating.

of 12 comments about the quality of intimacy shared with the person closest to the patient, ten reflect very good quality. My daughter and I have a very close relationship," "my husband is my whole life," and "my husband has been a tower of strength." The other two indicate Individuals who seemingly experience more sense of separateness from those around them: "Don't have anyone that close," "I'm not intimate with anyone." A "good" to "very good" rating was given once again; 
$(4.47)$

The entire scope of supportive relationships for the patient appeared to be very good. The grand mean for categories of friend, fam$11 y$, and intimacy was 4.40 , indicating that emotional support was strong.

\section{SPIRITUAL ASPECT AND LIFE CHOICES}

The spiritual side of kidney patients' lives was also explored. Most people felt that this part of their lives was "fair" to "good" (3.97). Of the 11 patients who commented here, responses came almost exclusively from patients who had faith in God (seven of 11) and expressed an acceptance of their disease. Most of those who commented expressed a sustaining faith in God as a helpful way to handle the problems of the disease. An example, "God has allowed this affliction to come into my life for a purpose. I only hope and pray I can fulfill that purpose."

The final area of overview for the patient population dealt with how patients viewed their choices in 11fe. Here patients rated aval1ability of IIfe choices as being "fair" to "good" (3.45). Three people commented that it was necessary to accept their disease and its Iimitations. Some expressed the need to search for new choices within the boundaries of their disease. Comments ranged from, "What cholces!?" and "I have no choices," to "Without the machine I wouldn't be living so it's great to be able to do anything" and "Lucky to be alive." 


\section{DESCRIPTION OF PATIENTS' RESPONSES \\ TO OPEN-ENDED QUESTIONS}

Because it was difficult to include all aspects within the structure of the questionnalre, three open-ended questions gave patients the opportunity to express attitudes and feelings which were not explored in earlier questions. The following tables describe these attitudes and feelings. It should be noted that the reliability of response categorization was not tested.

TABLE I

FACTORS SEEN AS CAUSING GREATEST CONCERN

(NUMBER RESPONDING AND PERCENT)

\begin{tabular}{lcccr}
\hline Responses & \multicolumn{3}{c}{ Home } & \multicolumn{2}{c}{ Center } \\
\hline Money worries, medical expenses & 7 & $20 \%$ & 5 & $24 \%$ \\
Health, physical condition & 4 & $11 \%$ & 4 & $19 \%$ \\
Being burden to family & 5 & $14 \%$ & 1 & $5 \%$ \\
Loss of helper (mate) & 2 & $6 \%$ & 2 & $10 \%$ \\
Concern for family & 4 & $11 \%$ & 0 & $0 \%$ \\
Work, employment & 0 & $0 \%$ & 3 & $14 \%$ \\
Chance of transplant & 2 & $6 \%$ & 0 & $0 \%$ \\
Positive answers or no worries & 5 & $14 \%$ & 3 & $14 \%$ \\
Other & 6 & $17 \%$ & 3 & $14 \%$ \\
$\quad$ TOTAL & & & & $100 \%$ \\
\hline
\end{tabular}

*Percentage does not equal 100 percent due to rounding

of the 56 patients who offered their feelings about their biggest worry, 24 percent of the center patients and 20 percent of the home 
patients found concern over financial worries and medical expenses to be the most pressing. The next aspect of most concern to them was their health and physical condition as indicated by 19 percent of center patients and 11 percent of home patients. Third, two somewhat dissimilar family related areas were sources of worry. In the first case, ten percent of center patients and six percent of home patients were worried about losing their spouse. In the other instance, 14 percent of the home patients and five percent of the center patients were concerned that they were burdens to their families.

A substantial number of both home and center patients, 14 percent, each either had no worries or gave positive types of answers. For example, "Everything is going wonderfully," "I really don't have any worries," and "Doesn't pay to worry."

The "other" category -- home, 17 percent and center, 14 percent -included a wide variety of individual concerns. One stated, "Living a full 1ife;" another related, (Worried about) "how I'm going to manage during winter time -- my husband should not be driving so far when the weather is bad." 
TABLE II

FACTORS SEEN AS IMPROVING QUALITY OF LIFE

(NUMBER RESPONDING AND PERCENT)

\begin{tabular}{|c|c|c|c|c|}
\hline Responses & \multicolumn{2}{|c|}{ Home } & \multicolumn{2}{|c|}{ Center } \\
\hline Improvement in health, physic & & & & \\
\hline condition & 6 & $18 \%$ & 7 & $32 \%$ \\
\hline Successful transplant & 5 & $15 \%$ & 4 & $18 \%$ \\
\hline More travel possible & 5 & $15 \%$ & 1 & $5 \%$ \\
\hline Shorter dialysis time & 1 & $3 \%$ & 2 & $9 \%$ \\
\hline Portable machine & 2 & $6 \%$ & 0 & $0 \%$ \\
\hline Improved finances & 5 & $15 \%$ & 0 & $0 \%$ \\
\hline Freedom to do more & 2 & $6 \%$ & 1 & $5 \%$ \\
\hline Employment, work & 0 & $0 \%$ & 2 & $9 \%$ \\
\hline Present quality satisfactory & 4 & $12 \%$ & 0 & $0 \%$ \\
\hline Other & 3 & $9 \%$ & 5 & $22 \%$ \\
\hline TOTAL & 33 & $99 \% *$ & 22 & $100 \%$ \\
\hline
\end{tabular}

*Percentage does not equal 100 percent due to rounding

Patient responses as to what could make the quallty of their lives better was clearly oriented toward improved physical condition. Both groups -- home patients, 18 percent and center patients, 32 percent -commented that an improvement in their health would make their lives more positive. Closely tied to this, 15 percent of the home patients and 18 percent of the center patients felt a successful transplant would bring improvement.

As was noted earlier, freedom to travel was important, and 15 
percent of the home patients and five percent of the center patients listed this.

Twelve percent of the home patients were satisfied with the present quality of their 11ves. For example, "My life is rich in quality (I have a wonderful wife and famtly)," and "I have all I want."

Finally, nine percent of home and 22 percent of center patients listed other factors which could Improve the quality of their lives. For example, "Don't give up and keep dolng what the doctors tell me," and "To think more positively."

TABLE III

ADDITIONAL PATIENT COMMENTS

\begin{tabular}{|c|c|c|c|c|}
\hline Responses & \multicolumn{2}{|c|}{ Home } & \multicolumn{2}{|c|}{ Center } \\
\hline No comments & 6 & $43 \%$ & 5 & $42 \%$ \\
\hline Appreciation to AKU staff & 3 & $21 \%$ & 2 & $17 \%$ \\
\hline Thankful for dialysis & 0 & $0 \%$ & 1 & $8 \%$ \\
\hline Treatment going well & 1 & $7 \%$ & 0 & $0 \%$ \\
\hline Glad to have home machine & 1 & $7 \%$ & 0 & $0 \%$ \\
\hline More communication between & & & & \\
\hline patients & 1 & $7 \%$ & 0 & $0 \%$ \\
\hline Condition hard to accept & 0 & $0 \%$ & 1 & $8 \%$ \\
\hline Doesn't like dialysis & 0 & $0 \%$ & 1 & $8 \%$ \\
\hline Other & 2 & $14 \%$ & 2 & $17 \%$ \\
\hline TOTAL & 14 & $99 \% *$ & 12 & $100 \%$ \\
\hline
\end{tabular}

*Percentage does not equal 100 percent due to rounding 
Twenty-one percent of home patients and 17 percent of center patients added that they were thankful to the Artificial Kidney Unit staff for providing "emotional and physical support," for "being so undersțanding," and for "good service" given by doctors and nurses.

Remaining comments fell into elther positive or negative categorles. Those that were positive were listed as: 1) thankful for dialysis, 2) treatment going well, and 3) glad to have a home machine. Among negative attitudes reported were finding the condition hard to accept and not 1iking dialysis.

One home patient made a specific suggestion about improving the Iife quality of dialysis patients: "Would like to see some sort of clearing house where patients can write in their problems, how they were solved, also how they spend their time."

\section{SUMMARY}

Subjective quality of life assessments are summarized as follows:

1. Activities of daily living -- Patients generally felt fair about such activities as a whole. They felt fair to good about lelsuretime activities. Almost three-fourths of the patients found social activities had changed, and this change was interpreted as poor to fair. Mobility restriction was labeled as fair.

2. Work and finances -- Over three-fourths of the patients were no longer employed and generally felt fair about this. Patients viewed their financlal situation as fair and reported that the overall financlal picture had changed somewhat.

3. Physical condition -- Patients felt falr to good about their 
general physical condition and those functions which play a major part of physical condition. Appetite was rated as good, sleep rated as fair to good, and changes in sex life concerned patients somewhat to considerably. Care of oneself was rated as falr to good.

4. Emotional state -- General emotional state was fair to good. Patients felt depressed sometimes to often. Concerning being tied down to dialysis, patients were little to somewhat bothered by this.

5. Supportive relationships -- Patients found support from friends as good to very good. Also, good to very good was family support and quality of intimacy shared with a significant other.

6. Spiritual aspect and 1ife choices -- In both of these areas patients felt fair to good.

In general, all areas mentioned above contained the full range of posstble ratings (very poor to very good). The areas of least satisfaction were physical condition and emotional state, and some aspects of dally activities. The most satisfactory areas were work and finances, supportive relationships, and spiritual aspects and life choices.

In response to the open-ended questions, patients were most worried about finances and medical expenses. It should be noted that a1though patients reported general satisfaction with financial circumstances, they continued to report finances as a major concern. Improvement in physical condition was judged as the best measure of improvement in quality of 1ife. Finally, patient appreciation to doctors and staff was the most common additional statement.

Now that a broad picture of home and center patients as a group has been drawn, a closer look will be taken at differences between the 
patient groups and correlations among the variables through statistical tests. 


\section{CHAPTER V}

\section{FINDINGS}

The purpose of this chapter is to present a quantitative analysis of the data emphasizing objective aspects derfved from statistical tests. Discriminant analyses were used to discriminate between the following:

1. home and center patient groups

2. home and center patient groups by sex

3. male and female patient groups

4. response grouplings categorlzed as poor to very poor, falr, and good to very good.

Factor analysis was utilized to determine if the 22 varlables could be reduced in number as well as to determine to what extent the variables were correlated. Throughout the study, statistical tests have been conducted at the .01 confidence level on the F-test and chi squares.

\section{STATISTICAL TESTS OF HOME AND CENTER PATIENT GROUPS}

An F-test was used to determine if a significant difference exIsted between home and center patients. Discriminant analysis over 22 variables on home and center patients yielded a $D^{2}$ of 24.053 . An F ratio of 10.83 ( 22 and $39 \mathrm{~d} . \mathrm{f}$. ) was significant at the .01 level of confidence.

The following table describes the results of discriminant analysis 
In home and center patient groups.

TABLE IV

EVALUATION OF CLASSIFICATION FUNCTION

FOR HOME AND CENTER PATIENTS

BASED ON DISCRIMINANT

ANALYSIS OF 22

VARIABLES

\begin{tabular}{lccc}
\hline & \multicolumn{2}{c}{ PREDICTION } & \\
\hline Patients & Center & Home & TOTAL \\
\hline Center & 19 & 8 & 27 \\
Home & 9 & 26 & 35 \\
& & & \\
\hline TOTAL & & & 62 \\
\hline
\end{tabular}

Using all 22 variables as predictors, 19 of 27 center patients are correctly identified while eight are incorrectly identified as home patients. Among 35 home patients, 26 are correctly identified as home patients and nine are incorrectly identified as center patients. Therefore, it is possible with 73 percent accuracy to predict whether a given dialysis patient in this study group can be Identified as either a center or home patient. The variables fall to discriminate in 27 percent of the cases.

These varlables indicate that there is a significant difference between home and center patients. That difference is a measure of the percelved difference in quality of life between the two groups. Home patients have a higher quality of life as indicated by their greater number of higher mean scores. This higher quality of life is particularly apparent in the areas of sleep, frequency of depression, ability to care for oneself, and quality of intimacy with significant other. 
In contrast, center patients exhlbited higher mean scores in such areas as mobility restrictions and present financial situation.

STATISTICAL TESTS OF HOME AND CENTER

PATIENT GROUPS BY SEX

A chi square was done to determine whether a significant difference existed among home and center patient groups by sex. Discriminant analysis over home and center patients by sex ylelded a $D^{2}$ of 90.948 significant at the .01 level (ch1 square, 66 d.f.).

The table below describes the results of discriminant analysis on home and center patient groups by sex.

TABLE V

EVALUATION OF CLASSIFICATION FUNCTION FOR HOME MALE AND FEMALE PATIENTS AND CENTER

MALE AND FEMALE PATIENTS BASED ON

DISCRIMINANT ANALYSIS OF

22 VARIABLES

\begin{tabular}{|c|c|c|c|c|c|}
\hline \multirow{3}{*}{$\begin{array}{l}\text { Sex and } \\
\text { Location }\end{array}$} & \multicolumn{4}{|c|}{ PREDICTION } & \multirow[b]{3}{*}{ TOTAI } \\
\hline & \multicolumn{2}{|c|}{ Center } & \multicolumn{2}{|c|}{ Home } & \\
\hline & Males & Females & Males & Females & \\
\hline \multicolumn{6}{|l|}{ Center } \\
\hline Males & 9 & 0 & 2 & 1 & 12 \\
\hline Females & 1 & 10 & 3 & 1 & 15 \\
\hline \multicolumn{6}{|l|}{ Home } \\
\hline Males & 1 & 1 & 11 & 3 & 16 \\
\hline Females & 2 & 0 & 3 & 14 & 19 \\
\hline TOTAL & & & & & 62 \\
\hline
\end{tabular}

of 28 home and center male patients, discriminant analysis indi- 
cates that nine are correctly identified as center males and 11 are correctly Identified as home males. Eight males among the 28 are not correctly identified. Among 34 home and center female patients, discriminant analysis indicates that ten are correctly identified as center females and 14 are correctly identified as home females. Ten females are incorrectly 1dentified. Therefore, it is possible to predict with 71 percent accuracy whether a given dialysis patient in this study group can be classified as either a male or female home patient or a male or female center patient on the basis of their responses. Adding the variable of sex does not significantly improve predictability. The variables fail to discriminate in 29 percent of the cases.

The chi square indicated a significant difference between home and center patients by sex. This difference, which indicates patients' percelved quality of life may be seen in the mean scores of the followIng variables. Center males had the lowest mean scores, and therefore, the lowest perceived quality of life, in the following areas: leisuretimc activities, satisfaction if not employed, general physical condition, changes in sex life, care of oneself, quality of intimacy with significant other, spiritual aspect, and choices in life. Home males had the highest mean scores indicating the highest perceived life satisfaction in the following areas: leisure-time activities, sleep, general emotional state, frequency of depression, feelings about being tied down to dialysis, emotional support from friends and family, spirItual aspect, and choices in iffe.

Mean scores of both home and center female groups occupy the midrange between home and center male groups. Exceptions to this for cen- 
ter females are indicated by low mean scores in sleep, general emotional state and frequency of depression: and by high mean scores in change in social activities and changes in sex life. The home females show low mean scores in belng tied down to dialysis, emotional support from friends and family; and by high mean scores in satisfaction if not employed, general physical condition, ability to care for oneself, and quality of Intimacy shared with significant other.

\section{STATISTICAL TESTS OF MALE AND} FEMALE PATIENT GROUPS

A ch1 square was conducted to determine whether a significant difference exdsted between male and female patient groups over all 22 variables. Discriminant analysis over 22 variables on male and female patients yielded a $D^{2}$ of 42.258 significant at the .01 level of confidence (ch1 square, 22 d.f.).

The table below describes the results of discriminant analysis on male and female patient groups.

TABLE VI

EVALUATION OF CLASSIFICATION FUNCTION FOR MALE AND FEMALE PATIENTS BASED ON DISCRIMINANT ANALYSIS OF 22 VARIABLES

\begin{tabular}{lccc}
\hline & \multicolumn{2}{c}{ PREDICTION } \\
\hline Sex & Male & Female & TOTAL \\
Male & 25 & 3 & 28 \\
Female & 7 & 27 & 34 \\
& & & \\
\hline TOTAL & & & 62 \\
\hline
\end{tabular}


of 28 male patients, discriminant analysis of the 22 variables Indicates that 25 are correctly identified as male patients while three are incorrectly identified as female patients. Among 34 female patients, 27 are correctly identified as female patients and seven are incorrectly identified as male patients. Therefore, it is possible with 84 percent accuracy to predict whether a given dialysis patient in this study group can be classified as either a male or female patient based on responses to the 22 variables. The varlables fail to discriminate in 16 percent of the cases.

A significant difference is indicated between male and female patients. This difference, Indicating quality of $11 f e$, is represented by mean scores of variables. As a group, mean scores of female patients Indicate that they have a higher quality of life than males, and this is particularly apparent in comparing mean scores of the following variables: changes in social activities, satisfaction if not employed, and changes in sex life. The only area in which males show a significantly higher mean score is in general emotional state.

\section{STATISTICAL TESTS OF RESPONSE GROUPINGS}

A chi square was done to determine if a signlficant difference existed among response groupings. Discriminant analysis over response groupings yielded a $\mathrm{D}^{2}$ of 96.590 significant at the .01 level (chi square, 44 d.f.).

The following table describes the results of discriminant analysis on grouped responses (good to very good, falr, and poor to very poor) to question 22 . This question, which measures perceived choices 
In $11 f e$, was tested to determine if it would function as a global indicator of responses to the other 21 questions.

TABLE VII

EVALUATION OF CLASSIFICATION FUNCTION

FOR TOTAL PATIENT GROUP BASED ON

RESPONSES TO CHOICES IN

LIFE QUESTION

\begin{tabular}{lcccc}
\hline & \multicolumn{3}{c}{ PREDICTION } & \\
\hline $\begin{array}{l}\text { Response } \\
\text { Group1ngs }\end{array}$ & $\begin{array}{c}\text { Poor to } \\
\text { Very Poor }\end{array}$ & Fair & $\begin{array}{c}\text { Good to } \\
\text { Very Good }\end{array}$ & TOTAL \\
\hline $\begin{array}{l}\text { Poor to } \\
\text { Very Poor }\end{array}$ & 11 & 0 & 2 & 13 \\
Fair & 0 & 11 & 3 & 14 \\
$\begin{array}{l}\text { Good to } \\
\text { Very Good }\end{array}$ & 2 & 3 & 29 & 34 \\
& & & & $61^{\star}$ \\
\hline
\end{tabular}

*One patient failed to respond to this question

of 13 responses in the poor to very poor category, 11 for question 22 are correctly placed by their responses to the other 21 questlons. Among the 14 responses in the falr category, 11 are correctly placed by their responses to the other 21 questions. of 34 responses in the good to very good category, 29 are correctly placed in this category. However; ten responses are misplaced in other categories. Therefore, it is possible to predict with 84 percent accuracy (51 out of 61 correctly placed responses) dialysis patients' responses to the other 21 questions based on their response to question 22 . The var1ables fall to discriminate in 16 percent of the cases. 
ROTATED FACTOR ANALYSIS OF 22 VARIABLES

A rotated factor analysis of 22 variables was conducted. The manner in which responses were grouped does reflect the way in which the 22 variables were grouped in the questionnaire. The degree to which the 22 varlables are reduced to eight dimensions accounts for 76 percent of the total information contained in the original 22 variables. These eight dimensions closely overlap the six 11 fe satisfaction categories described in Chapter IV, but also include the additional categories of Intimacy and general satisfaction. Furthermore, each of the eight dimensions is independent of the others (see Appendix $\mathrm{C}$ ).

Seven dimensions contain clusters of two to five variables while the remaining dimension is represented by only one varlable. Within the emotional state dimension, five variables are present: general emotional state, frequency of depression, feelings about being tied down to dialysis, care of oneself, and choices in life. The second dimension, employment, contains three variables: employment status, performance satisfaction if employed, and satisfaction if not employed. Soclal activities as the third dimension contains the following variables: change in social activities and positive or negative change in social activities. The fourth dimension, emotional support, includes two variables: emotional support from friends and emotional support from family. Finances constitutes the fifth dimension and contains the following variables: financial situation and change in financial situation due to dialysis. The sixth dimension, intimacy, contains a single varlable: quality of intimacy with significant other. It is not 
correlated with any of the other 21 variables. The seventh dimension, physical condition, contains four variables: leisure-time activities, mobility restrictions, general physical condition, and changes in sex 11fe. The final dimension, general satisfaction, contains five variables: general physical condition, appetite, sleep, spiritual aspect, and choices in life.

In four of the dimensions, correlations of variables appeared that were unanticipated. Within the first dimension, the variable of cholces In 11 fe was percelved by patients as being directly linked to the dimension of emotional state.

The sixth dimension, intimacy, constitutes a separate dimension. Because of this, it is not apparently linked with variables dealing with emotional support from friends or family or with changes in sex Iife.

In dimension seven, it was anticipated that lelsure-time activitles and mobility restrictions would be linked and that general physical condition and changes in sex life would also be interrelated. However, the intercorrelation of these four variables in the same dimension was not anticipated.

Within the eighth dimension, general physical condition, appetite, and sleep were expected to be 1inked; also, spiritual aspect and choices in 1ife were assumed to be interrelated. However, the intercorrelations of these five variables in this same dimension was not anticipated.

While the correlations are significant, standard deviations of the items on the five-point scale were relatively large, indicating a 
need for caution in drawing quantitative inferences on individual items.

\section{SUMMARY}

This chapter has presented a quantitative analysis of the data through statistical testing. Three statistical tests were utilized to determine whether there was significant difference between the patient groups studied, whether directions of these differences could be determined from mean scores, and whether predictions could be made about the classification of patient groups.

According to an F-test, a significant difference was found between home and center patients. A close look at mean scores of the variables studied revealed that home patients had a higher quality of Iife than center patients. It was also determined through discriminant analysis that a particular patient could be identified as either a home or center patient according to his or her responses to the 22 variables studied.

A chi square on home and center patients by sex, showed that there was a significant difference between these four groups. Mean scores indicated that home males had the highest quality of life and center males the lowest. Further, discriminant analysis determined that patients could be classified as either home or center males, or home or center females, based on their responses to the 22 variables. Again, a significant difference was found between male and female patients by use of a ch1 square. Female patients were determined to have a higher quality of life than male patients by examination of mean scores. Discriminant analysis indicated that a particular patient 
could be identified, according to responses to the 22 variables, as efther male or female.

Discriminant analysis also indicated it was possible to predict patient responses to 21 of the questions based on responses to one global question: choices in $11 \mathrm{fe}$.

Factor analysis determined it was posstble to reduce the 22 vartables to elght independent dimensions and still capture approximately three-fourths of the information. The same statistical test produced correlations of variables within dimensions that were anticipated, and In a few cases, some that were not expected. 


\section{CHAPTER VI}

\section{SUMMARY}

This study represents a preliminary attempt to assess the quality of life of a responding population of chronic dialysis patients. To accomplish this, a questionnaire was employed to elicit subjective responses focused on particular life satisfaction categories. It was determined that there was a significant difference between patient groups in both qualitative and quantitative assessments. Home patients as a group, female patients as a group, and home male patients as a group all reported higher quality of 11 fe based on mean scores of the 22 variables examined in this study. These findings have implications for social work with dialysis patients, as well as for further research In this area.

\section{SOCIAL WORK IMPLICATIONS}

Dialysis patients must deal with a great variety of physical and psycho-social problems, and positive adjustment to these represents a major achievement. Toward this end, social workers need to be cognizant of the following implications in their work with these patients.

1. Efforts designed to Improve quality of life of dialysis patients must take into account the apparent differences in characteristics exhibited by home patients as a group in contrast with center patients as a group. For example, home patients felt better able to care 
for themselves than center patients; whereas center patients felt more positive about restrictions on their mobility.

2. Home and center patient groups have considerably different characteristics, but within each group much similarity exists. Therefore, treatment should not be stereotyped by group, but common treatments can be looked for.

3. Chronic renal failure is among the class of diseases which results in extremely pervasive ramifications in all areas of the patient's life. Because of this, the social worker must be prepared to deal with a wide variety of personallty types under extremely stressful circumstances. Whether a given patient responds well or poorly to such circumstances depends in large part on maturity, how previous stresses were handled, and on family strengths and supports.

4. Because dialysis patients nearly always experience intense combinations of internal and external stress, there is a tendency to react unrealistically efther through excessive denial or through being overly anxious.

5. Findings from this study point to correlations of certain variables. Because of this, the soctal worker should be attuned to the possibility that he or she may be dealing with a patient who has a particular presenting problem which may in fact consist of several related variables. For example, if a problem concerning sex occurred, the worker should also consider the influence of the possibly related variables of general physical condition, leisure-time activities, and mobility restrictions.

6. In viewing the eight dimensions which were reduced from the 
22 variables, the worker should be aware of their mutual independence. For example, the findings indicate that patients' social activities should not be viewed as a function of their physical activities.

7. In view of the rapidly changing economic, social, and medical environments in which these patients are enmeshed, it is essential that social workers involved with dialysis patients remain alert to new developments which could enhance their quality of life. Such developments may include further extension of national health coverage benefits for such catastrophic illness, the training of paramedics to relieve family members from complete responsibility of assisting with home dialysis runs, and the increasing feasibility that portable kidney machines will become widely available.

8. A final implication to be kept in mind involves the recent advances in medical technology. The result is a controversial dialogue focused on patients' rights to determine the course of their own lives versus heroic life-saving efforts. Decisions to begin or continue dialysis treatments now involve complicated moral and ethical considerations which reflect the continuing search to find a balance between a sufficiently satisfying quality of Iffe and the alternative choice of death.

\section{RESEARCH IMPLICATIONS}

Given the paucity of studies dealing with life quality assessment of dialysis patients, the need for additional research studies is readily apparent. The following are suggestions for further explorations in this area.

1. This study presents a preliminary effort to assess the life 
quality of dialysis patients at a given point in time. Longitudinal studies are needed for the examination of variables over time which may point to causal relationships or reveal the presence of new variables:

2. A combination of pre- and post-dialysis life quality assessments could be conducted to determine changes in attitudes and feelings in relation to a particular treatment regimen. Such changes could make possible more refined medical treatment especially with regard to placing a patient in either home or center treatment regimen, as well as provide focus for social service interventions.

3. New varfables which resulted from the comments and open-ended questions could be examined as possible indicators of life quality satisfaction in future studies.

4. Because factor analysis of the 22 variables indicated that they could be reduced to eight dimensions, future questionnaires could include a representative question from each dimension thereby reducing the overall length of the present questionnaire.

\section{CRITIQUE OF STUDY}

In the course of assessing and evaluating this study the reader should be cognizant of certain limftations and cautions.

1. The study was not intended to be a causal study.

2. The reader should be cautious in drawing conclusions or inferences from the results of this study. Broad generalizations should not be drawn and applied to other kidney dialysis patient populations; outcomes of this study can only be applied to the patient group that was surveyed. Implications from the data are broad in nature, and may 
obscure individual differences. It is important that each patient be dealt with on an individual basis.

3. It should be remembered that this study was a cross-section of kidney dialysis patients at a specific point in time and that no assumptions should be made with respect to other variables. Furthermore, the patients in this study represent a small number (.30 percent) of the current U.S. kidney dialysis population.

4. Representativeness of home and center groups responding to the questionnalre was not tested. Seventy-five percent of the home patients responded ( 35 out of 47). Fifty-nine percent of the center patients responded ( 27 out of 46$)$.

5. The rater reliability of the open-ended categorizations in Tables I, II, and III was not tested.

CONCLUSION

This study of chronic dialysis patients at Good Samaritan Hospital and Mediçal Center has been a preliminary effort Intended to explore the impact of certain varlables on the 11fe quality of these patients. Further research is needed to follow-up on initial findings presented herein and to expand the knowledge base of those who are in a position to improve service delivery. 


\section{REFERENCES}

1. Abram, Harry S. "Psychiatric Reflections on Adaptation to Repet1tive Dialysis." Kidney International. Vol. 6: 67-72, 1974.

2. - "Suicidal Behavior in Chronic Dialysis Patients." American Journal of Psychiatry. Vol. 127: 1199-1204, 1971.

3. - "The Psychlatrist, the Treatment of Chronic Renal Failure, and the Prolongation of LIfe: II." American Journal of Psychlatry. Vol. 124: 157-167, 1969.

4. Anderson, K. "The Psychological Aspects of Chronic Hemodialysis." Canadian Psychiatric Association Journal. Vol. 20, No. 5: 385-391, 1975.

5. Buchanan, Denton C. and Abram, Harry S. "Psychological Adaptation to Hemodialysis." Dialysis and Transplantation. Vol. 2, No. 2: 40-42, 1976.

6. Cummings, Jonathan W. "Hemodialysis -- Feelings, Facts, Fantasies." American Journal of Nursing. Vol. 70: 70-76, 1970.

7. De-Nour, A. Kaplan and Czaczkes, J. W. "Emotional Problems and Reactions of the Medical Team in a Chronic Hemodialysis Unit." The Lancet. Nov. 9, 1968.

8. De-Nour, Atara Kaplan, Shaltiel, Judith, and Czaczkes, J. W. "Emotional Reactions of Patients on Chronic Hemodialysis." Psychosomatic Medicine. Vol. 30, No. 5: 521-533, 1968.

9. Federal Register. Vo1. 41, No. 108: 22,517-22,518. Thursday, June 3, 1976:

10. Goldstein, Alan M. and Reznikoff, Marvin. "Suicide in Chronic Hemodialysis Patients from an External Locus of Control Framework." Amertcan Journal of Psychlatry. Vol. 127, No. 9: $124-127,1971$.

11. Greenberg, Irwin M., Weltz, Sharon, Spitz, Cathy, and Bizzozero, 0. Joseph. "Factors of Adjustment in Chronic Hemodialysis $\mathrm{Pa}$ tients." Psychosomatics. Vol. 16: 178-183, 1975.

12. House, Peter W., Livingston, Robert C., and Swinburn, Carol D. "Monitoring Mankind: The Search for Quality." Behavioral Science. Vo1. 20: 57-67, 1975. 
13. Landsman, Melanle K. "The Patient with Chronic Renal Failure: A Marginal Man." National Kidney Foundation Professional Membership Application. Reprints avallable from author, 3341 Warrensville Center Road, 非107, Cleveland, Oh1o, 44122 .

14. McKegney, F. P. and Lange, Paul. "The Decision to No Longer Live on Chronic Hemodialysis." American Journal of Psychiatry. Vol. 128: 267-274, 1971 .

15. Neff, Martin. "Center Vs. Home Dialysis." Renal News. Vo1. 5: 17-18, Spring 1975.

16. Scribner, B. H., BurI, R., Caner, J-E. Z., Hegstrom, R., and Burne11, J. M. "The Treatment of Chronlc Uremia by Means of Intermit tent Hemodialysis, a Preliminary Report." Transactions of the American Society of Artificial Internal Organs. Vol. 6: 114-121, 1960 .

17. U.S. Department of Health, Education, and Welfare. Living with End Stage Renal Disease. Public Health Service Publication No. 76-3001. Washington, D.C.: Government Printing office.

18. Viederman, Milton. "Adaptive and Maladaptive Regression in Hemodialysis." Psychlatry. Vol. 37: 68-77, 1974.

19. Wright, Robert G. "Psychological stress During Hemodialysis for Chronic Renal Failure." Annals of Internal Medicine. Vol. 64, No. 3: 611-621, 1966 . 
APPENDIX A:

QUESTIONNAIRE 
Please circle the word that best fits for you. Space for comments has been left after each question and we encourage you to use it. You may use the back of the sheet for longer comments.

1. Concerning leisure-time activities, which of the following best describes how you feel about them?

\begin{tabular}{llccc}
5 & 4 & 3 & 2 & 1 \\
\hline $\begin{array}{l}\text { Very } \\
\text { Good }\end{array}$ & Good & Fair & Poor & $\begin{array}{l}\text { Very } \\
\text { Poor }\end{array}$
\end{tabular}

Comments :

2. Has your involvement in social activities changed? Yes No

3. If YES, how would you rate that change?

\begin{tabular}{ccccc}
5 & 4 & 3 & 2 & 1 \\
\hline $\begin{array}{c}\text { Much } \\
\text { Better }\end{array}$ & Better & $\begin{array}{c}\text { A } \\
\text { Bittle } \\
\text { Better }\end{array}$ & Worse & $\begin{array}{l}\text { Much } \\
\text { Worse }\end{array}$
\end{tabular}

Comments:

4. How do you feel about the restrictions on your ability to get around (shopping, sports, social activities, travel, etc.) required by dialysis?

\begin{tabular}{lcccc}
5 & 4 & 3 & 2 & 1 \\
\hline $\begin{array}{l}\text { Very } \\
\text { Good }\end{array}$ & Good & Falr & Poor & $\begin{array}{l}\text { Very } \\
\text { Poor }\end{array}$
\end{tabular}


4. continued

Comments :

5. Are you employed?

Yes

No

6.

If YES, how are you dolng at work?

\begin{tabular}{ccccc}
5 & 4 & 3 & 2 & 1 \\
\hline $\begin{array}{l}\text { Very } \\
\text { Well }\end{array}$ & Well & Fair & Poorly & $\begin{array}{c}\text { Very } \\
\text { Poorly }\end{array}$
\end{tabular}

Commen ts :

7.

If NO, how do you feel about that?

\begin{tabular}{lcccc}
5 & 4 & 3 & 2 & 1 \\
\hline $\begin{array}{l}\text { Very } \\
\text { Good }\end{array}$ & Good & Fair & Bad & $\begin{array}{l}\text { Very } \\
\text { Badly }\end{array}$
\end{tabular}

Comments :

8. How do you view your financial situation at present?

\begin{tabular}{lcccc}
5 & 4 & 3 & 2 & 1 \\
\hline $\begin{array}{l}\text { Very } \\
\text { Good }\end{array}$ & Good & Fair & Poorly & $\begin{array}{c}\text { Very } \\
\text { Poorly }\end{array}$
\end{tabular}

Comments: 
9. How has the cost of dialysis changed your financial picture?

\begin{tabular}{ccccc}
5 & 4 & 3 & 2 & 1 \\
\hline $\begin{array}{l}\text { Areat } \\
\text { Deal }\end{array}$ & Considerably & Somewhat & Little & $\begin{array}{c}\text { Very } \\
\text { Little }\end{array}$
\end{tabular}

Comments :

10. Which of the following describes how you feel physically most of the time?

\begin{tabular}{ccccc}
5 & 4 & 3 & 2 & 1 \\
\hline $\begin{array}{l}\text { Very } \\
\text { Good }\end{array}$ & Good & Falr & Poorly & $\begin{array}{c}\text { Very } \\
\text { Poorly }\end{array}$
\end{tabular}

Comments:

11. How is your appetite?

\begin{tabular}{ccccc}
5 & 4 & 3 & 2 & 1 \\
\hline $\begin{array}{l}\text { Very } \\
\text { Good }\end{array}$ & Good & Fair & Poor & $\begin{array}{l}\text { Very } \\
\text { Poor }\end{array}$
\end{tabular}

Comments :

12. Which of the following best describes how you sleep?

\begin{tabular}{ccccc}
5 & 4 & 3 & 2 & 1 \\
\hline $\begin{array}{l}\text { Very } \\
\text { Good }\end{array}$ & Good & Falr & Poorly & $\begin{array}{c}\text { Very } \\
\text { Poorly }\end{array}$
\end{tabular}


12. continued

Comments :

13. Are you concerned about changes in your sex life?

\begin{tabular}{ccccc}
5 & 4 & 3 & 2 & 1 \\
\hline $\begin{array}{l}\text { Areat } \\
\text { Deal }\end{array}$ & Considerably & Somewhat & Little & Vittle
\end{tabular}

Comments :

14. Which of the following describes how you feel emotionally most of the time?

\begin{tabular}{lcccc}
5 & 4 & 3 & 2 & 1 \\
\hline $\begin{array}{l}\text { Very } \\
\text { Good }\end{array}$ & Good & Fair & Poor & Pery
\end{tabular}

Comments :

15. How often are you depressed?

\begin{tabular}{ccccc}
5 & 4 & 3 & 2 & 1 \\
\hline $\begin{array}{l}\text { Very } \\
\text { Often }\end{array}$ & often & Sometimes & Seldom & $\begin{array}{c}\text { Very } \\
\text { Seldom }\end{array}$
\end{tabular}

Comments: 
16. How much are you bothered by being "tled down" to dialysis?

\begin{tabular}{ccccc}
5 & 4 & 3 & 2 & 1 \\
\hline $\begin{array}{l}\text { Areat } \\
\text { Deal }\end{array}$ & Considerably & Somewhat & Little & Vittle
\end{tabular}

Comments:

17. How do you view your abllity to care for yourself?

$\begin{array}{lcccc}5 & 4 & 3 & 2 & 1 \\ \begin{array}{l}\text { Very } \\ \text { Good }\end{array} & \text { Good } & \text { Fair } & \text { Poor } & \text { Very }\end{array}$

Comments:

18. In general, how emotionally supportive are your friends?

$\begin{array}{ccccc}5 & 4 & 3 & 2 & 1 \\ \begin{array}{c}\text { Very } \\ \text { Supportive }\end{array} & \text { Supportive } & \text { Somewhat } & \begin{array}{c}\text { Not Very } \\ \text { Supportive }\end{array} & \begin{array}{c}\text { Non- } \\ \text { Supportive }\end{array}\end{array}$

Comments:

19. How do you feel about the emotional support you get from your family?

\begin{tabular}{lcccc}
5 & 4 & 3 & 2 & 1 \\
\hline $\begin{array}{l}\text { Very } \\
\text { Good }\end{array}$ & Good & Fair & Poor & Very
\end{tabular}


19. continued

Comments :

20. Which of the following best indicates the quality of intimacy you share with the person closest to you?

\begin{tabular}{ccccc}
5 & 4 & 3 & 2 & 1 \\
\hline $\begin{array}{l}\text { Very } \\
\text { Good }\end{array}$ & Good & Falr & Poor & Pery
\end{tabular}

Comments :

21. Which of the following best describes how you feel about the spiritual side of your Iffe?

\begin{tabular}{ccccc}
5 & 4 & 3 & 2 & 1 \\
\hline $\begin{array}{l}\text { Very } \\
\text { Good }\end{array}$ & Good & Fair & Poor & Pory
\end{tabular}

Comments:

22. How do you feel generally about the cholces of life that are aval1able to you?

$\begin{array}{lcccc}5 & 4 & 3 & 2 & 1 \\ \begin{array}{l}\text { Very } \\ \text { Good }\end{array} & \text { Good } & \text { Fair } & \text { Poor } & \begin{array}{l}\text { Very } \\ \text { Poor }\end{array}\end{array}$

Comments: 
With the following questions we encourage you to bring up any important areas that we have not covered. Please use the back of the sheet if you need more space.

23. What would you say is your biggest worry?

24. What could make the quality of your life better?

25. Are there any additional comments you would like to make? 
The following section will help us categorize responses of all participants.

Age

$$
\text { Yrs. }
$$

Sex

$$
\overline{\mathrm{M}, \mathrm{F}}
$$

Mar1tal Status $\overline{\mathrm{M}, \mathrm{D}, \mathrm{S}, \mathrm{W}}$

W1th whom do you live (mark all applicable):

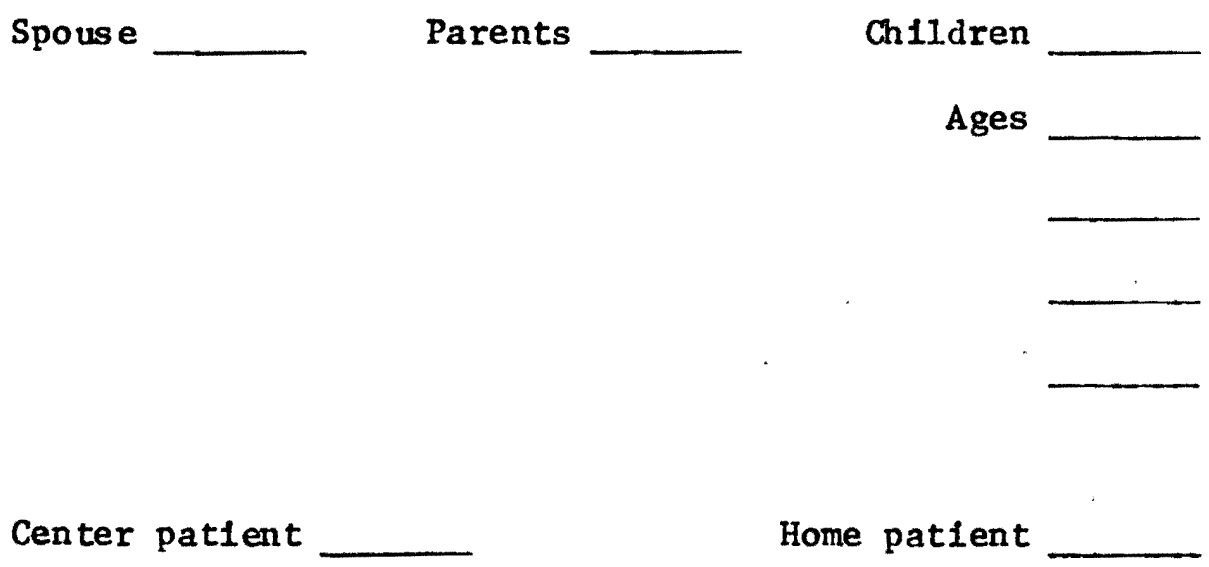

How long have you been on dialysis

Yrs.

Mos.

THANK YOU VERY MUCH:

This questionnaire is strictly confidential. The number at right is for tabulating purposes only. It will be removed immediately upon recelpt of the questionnaire. 
APPENDIX B :

DEMOGRAPHIC PROFILE OF STUDY POPULATION 
TABLE VIII

DIALYSIS PATIENTS BY AGE

NUMBER PERCENT

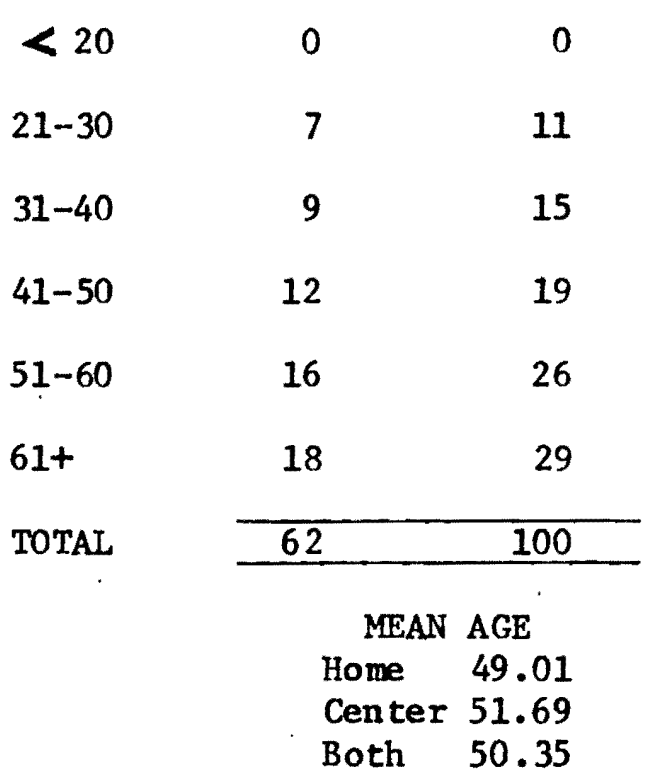

TABLE IX

DIALYSIS PATIENTS BY SEX

\begin{tabular}{ll}
\hline \multicolumn{2}{c}{ MALE } \\
\hline Number & FEMALE \\
\hline
\end{tabular}

HOME

16

45.7

19

54.3

CENTER

44.4

15

55.6 
TABLE X

DTALYSIS PATIENTS BY MARITAL STATUS

\begin{tabular}{lcccc} 
& \multicolumn{2}{c}{ HOME } & \multicolumn{2}{c}{ CENTER } \\
\cline { 2 - 5 } & Number & Percent & Number & Percent \\
\cline { 2 - 5 } Married & 31 & 88.6 & 19 & 76 \\
Divorced & 1 & 2.8 & 4 & 16 \\
Single & 2 & 5.8 & 0 & 0 \\
Widowed & 1 & 2.8 & 2 & 8 \\
TOTAL & 35 & 100 & 25 & 100 \\
\hline
\end{tabular}

TABLE XI

DIALYSIS PATIENTS BY MARITAL

STATUS AND SEX

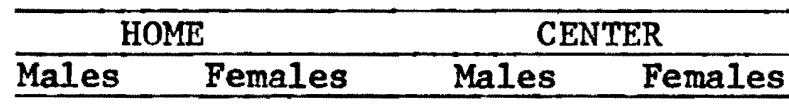

MARRIED

14

17

10

9

DIVORCED

0

1

2

2

SINGLE

2

0

0

0

WIDOWED

0

1

0

2 
TABLE XII

PERSON (S) WITH WHOM PATIENT LIVES

HOME CENTER

\begin{tabular}{lrr} 
Spouse & 31 & 19 \\
Children & 15 & 9 \\
Parent & 2 & 1 \\
Self & 2 & 3 \\
Other & 0 & 2 \\
\hline
\end{tabular}

TABLE XIII

AGE AND NUMBER OF PATIENTS' CHILDREN

\begin{tabular}{lcc}
\hline AGE OF CH ILDREN & HOME & CENTER \\
\hline 18 and Under & 21 & 8 \\
Over 18 & 9 & 8 \\
\hline TOTAL & 30 & 16 \\
\hline
\end{tabular}


TABLE XIV

AVERAGE NUMBER OF CHILDREN PER FAMILY

HOME CENTER

Under 18

$1.4 \quad .89$

TOTAL

\begin{tabular}{l}
$2 \quad 1.78$ \\
\hline
\end{tabular}

TABLE XV

LENGTH OF TIME ON DIALYSIS

\begin{tabular}{lcc}
\hline MONTHS & NUMBER & P ERCENT \\
\hline $0-12$ & 31 & 50 \\
$13-24$ & 7 & 11 \\
$25-36$ & 13 & 21 \\
$37-48$ & 5 & 8 \\
$49-60$ & 2 & 3 \\
$61-72$ & 1 & 2 \\
$73-84$ & 2 & 3 \\
$85-96$ & 1 & 2 \\
\hline TOTAL & 62 & 100 \\
\hline
\end{tabular}

MEAN LENGTH OF TIME ON DIALYSIS

Home 22.88

Center 19.11

Both 21.00 
APPENDIX C:

ROTATED FACTOR MATRIX

OF 22 VARIABLES 
TABLE XVI

ROTATED FACTOR MATRIX OF 22 VARIABLES*

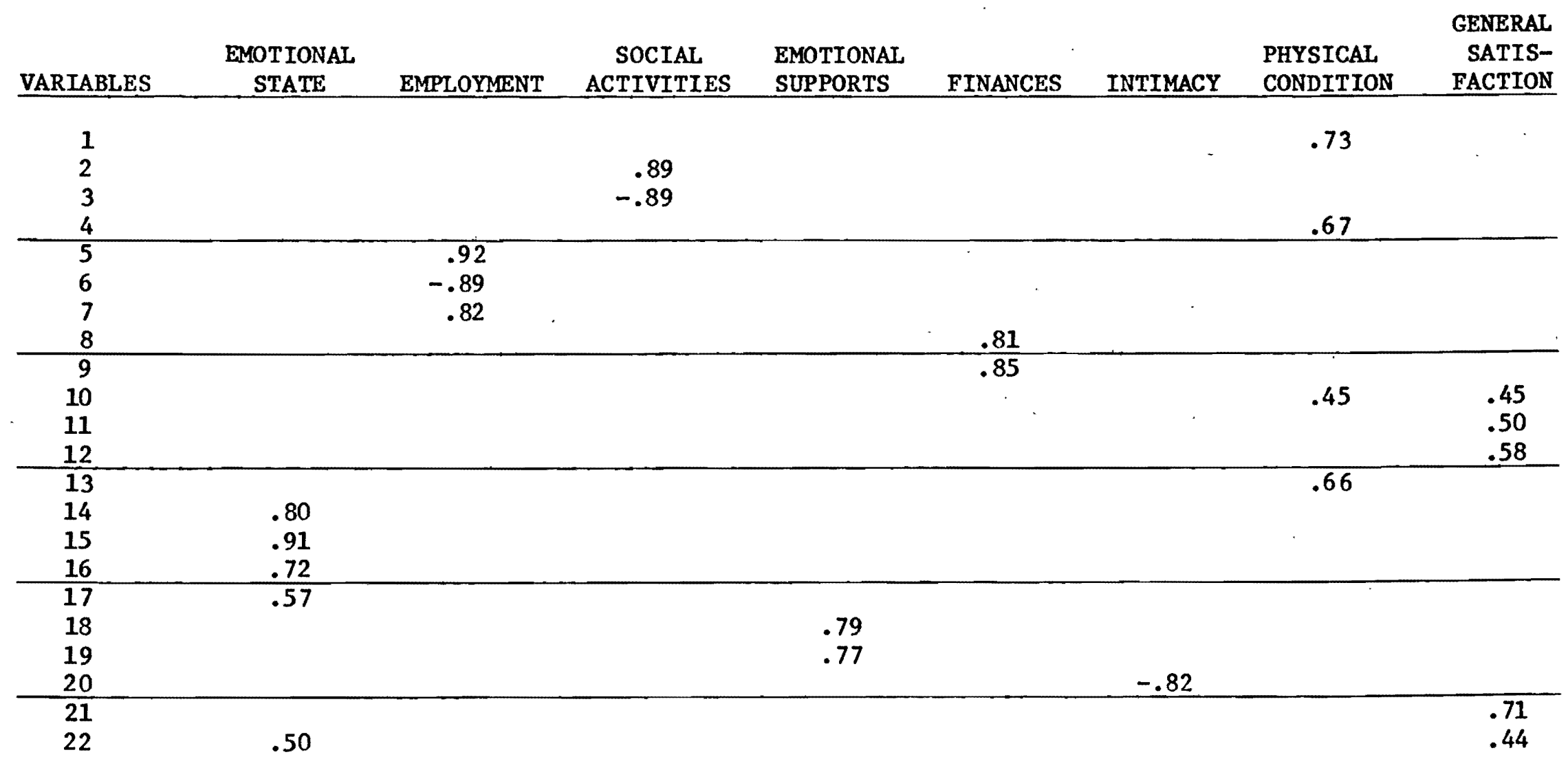

*only correlations .44 or greater appear in this table 